\title{
Vygotsky's Legacy on Teaching and Learning Writing as Social Process
}

\section{Sitti Nurfaidah}

Institut Agama Islam Negeri Kendari.Email:sitti.nurfaidah.haddad@gmail.com

\begin{tabular}{l} 
ARTICLE INFO \\
\hline Keywords: \\
Activity Theory; \\
Reflection; Scaffolding; \\
Sociocultural; Teaching \\
and Writing; Vygotsky \\
How to cite: \\
Nurfaidah, S. (2018). \\
Vygotsky's Legacy on \\
Teaching and Learning \\
Writing as a Social \\
Process, 4(2), 149-156. \\
DOI: \\
http://dx.doi.org/10.31332/ \\
lkw.v4i2.1038
\end{tabular}

\begin{abstract}
Vygotsky has imprinted many influences on learning and teaching learning development. Although his main works focus on psychological aspects of children's learning, they are very useful both for the teachers and researchers in understanding and exploring the best they can do for the development of the students' learning. One of Vygotsky's legacy can be traced in the process of teaching and learning writing in which this skill is regarded as social process. Scholars believe that his idea on sociocultural perspective becomes the foundation in giving scaffolding in teaching writing, collaborative work activity in writing lesson, as well as teachers reflection on their teaching and learning activities in the classroom, as much as the teaching and learning writing as social process. This article, therefore, represents review on Vygotsky's influences on language learning and teaching development, particularly in writing which is considered as social process.
\end{abstract}

\section{Introduction}

Vygotsky's influence has been imprinted on many scholars' scientific work (Lantolf, 2011; Reitbauer \& Fromm, 2016; Zeichner, Payne, \& Brayko, 2014; Zhang, 2013) in many ways of teaching and learning development. In the educational field, Vygotsky's legacy can be traced through his Zone of Proximal Development (ZPD) theory (Vygotsky, 1986), scaffolding strategies (Vygotsky, 1978), and further expansion of his Zone of Proximal Development theory into activity theory (Engestörm, 2001). All these theoretical constructs are grounded on socioconstructivist perspective within the sociocultural theory that regards human cognitive development typically prevails in social interaction with assistance being provided by the expert members within the society (Lantolf, 2011; Storch, 2018).

As far as teaching and learning writing are concerned, sociocultural theory and activity theory is of great importance in understanding the learners' development in their learning milieu as well as the teachers' intervention to the students' progress (Engestörm, 2001; Lantolf, 2011; Zacharias, 2014). In teaching writing, instructional activities are underpinned by the social process (Cheung, 2016; $\mathrm{Xu}, 2016$ ). The teachers are considered as the more knowledgeable other (Vygotsky, 1978) since their constructive role in the learners' development in providing the needed social instruction within the classroom context (Wilson \& Devereux, 2014). 
Social engagement and contribution also play a key role in students' learning process as they are involved more in collaborative work (Ammar \& Hassan, 2018). Reflective teaching practice is also rooted in a sociocultural perspective (Shokouhi, Moghimi, \& Hosseinzadeh, 2015) since teachers' reflection on their teaching and learning activities in the classroom not only portrays their existence as social agent, the more knowledgeable others towards their students, but also as parties seeking assistance from other experts in terms of teaching and learning as social process.

\section{Vygotsky's Sociocultural Perspective}

The sociohistorical perspective grasped by Vygotsky (1978) comes from his belief that there is a strong relationship between culturally organized experiences and learning. This idea is very useful in teaching learning in general since it emphasizes how interactions between people become the most important mechanism by which learning and development occur. The key assumption of this idea is that the intellectual skills acquired by children are regarded to be directly related to their interaction with adults and peers in specific problem-solving environments. In other words, children internalize any help adults of other more capable people given to them which sooner or later they make use of in directing their subsequent problemsolving behaviors. In this sense, the interaction between people and individual psychological processes rely on an explicit and direct connection. Therefore, the role of the teacher, peers, and others in the teaching and learning process is of a pivotal point since others' development can be driven through their assistance in social bond (Samana, 2013).

\section{Scaffolding}

Vygotsky himself has never used the term scaffold or scaffolding. However, the theorists and researchers in sociocultural perspective use this term to a large extent, and very much link it to Vygotsky's theory in adult-child interaction, to describe about the interactional support given by adult to children, usually in form of dialogue, in order to make the most out of the children's growth in terms of their inter psychological functioning. There are many examples describing how children function independently, which works in writing as well, after being exposed to collaborative work that adult showed them in their interaction.

In a class where the teacher is teaching writing focusing on a topic titled $M y$ Family, for example, the scaffolding might come in various ways. For instance, before going to the writing task, the teacher might come with prompting a picture of a family and ask the children to identify them. After that, the teacher continues with asking some students about their own family and their life. In this state, the teacher explores students' knowledge by prompting constructive activity through some constructive questions. The teacher then might accept the students' involvement, work with new knowledge, or even accept partially correct responses, and keep prompting constructive activities. Through this way, the students are helped by the teacher to come up with their problem solving as independently as they do (Lantolf, 2011).

In other words, the teacher is scaffolding the writing lesson by expanding the students' knowledge of what they are already familiar with and what they are not familiar with yet. The teacher deals with the unfamiliar things for the students by 
measuring their learning capacity as well as keep motivating the students by giving constructive feedback to their slips and errors (Lee, 2014). In such a way, the teacher then can come to modeling the writing in such topic with the idea that the students have mostly understood what the text is all about. In the progress of writing, therefore, the teacher will shift further to individual's comprehension through detecting and giving help in a constructive way on the slips or errors when they take place. Through this scaffolding activity, the teacher encourages the learners to have their control so that eventually they will get used to involve in a more independent, constructive activity.

\section{Activity Theory}

Activity theory proves to be one of Vygotsky's legacies in teaching and learning writing. The theory itself is the expansion of Leontev's activity theory (1974) and Vygotsky's zone of proximal development (1978) by Engestörm (2001). This theory emphasizes the influence of macro-structures and socio-political contexts as simultaneous constraints in human activity. Under this theory, teachers and learners' behavior can be analyzed and observed (Storch, 2018). Activity theory is useful in identifying the teachers' feedback practices to students' work, for example. The teachers' underlying motives and drives in giving certain feedback can be revealed. Similarly, students' ways of responding to feedback given to them could also be investigated (Storch, 2018).

Regarding teaching and learning writing, activity theory operates on learners' participation in such an activity system which requires the learners to use strategies when dealing with writing task that needs to be fulfilled. As feedback from the teachers operates on scaffolding schema, learners locate some strategies to develop more in their learning process. Strategies such as self-revision, asking for peer revision or other ways foster the learners' independence and editing skill in writing. Teachers, in turn, have the responsibility to provide feedback to the learners appropriate to their individual needs.

\section{Zone of Proximal Development and Collaborative Workin Writing}

When teachers decide to make use of collaborative work in their classes, they are dealing with Vygotsky's Zone of Proximal Development in which the more competent peers are believed to be able to support learners' development (Vygostky, 1978). Most research has proven that students who work in collaboration with the more knowledgeable others or more capable people almost always manage to work on the task given successfully. In Ammar and Hassan's (2018) recent empirical study, for example, collaborative activity in the form of collaborative dialogue proves to benefit both the high- and low-proficiency learners. Teachers are the key factor in helping the learners to move through their zone of proximal development by providing appropriate scaffolding. In this way, teachers contribute to developing the low-proficiency students' willingness to talk about their linguistic problem or language constraints. In other words, teachers have the responsibility to students' learning process by exposing them to problem solution context while at the same time raising their awareness of constructive values of society (Mayordomo \& Onrubia, 2015). 
In the case of learning writing under collaborative work, social interaction strengthens the learners' levels of shared meanings elaboration (Mayordomo \& Onrubia, 2015). When collaborative activities take place in the zone of proximal development, the more capable peer is encouraged to offer help to the others. The process of negotiating, constructing and reconstructing knowledge and new meaning takes place within a natural shared knowledge construction phase. Mayordomo and Onrubia (2015) suggest that teachers or educators pay more attention to "shared regulation" (p. 103) in collaborative writing tasks. Also, they further suggest that teachers should put more concern on their students when they are involved in group work in a way that the coordination among the teamwork could enhance the process of collaborative knowledge construction and collaborative writing.

\section{Teacher Reflection as Social Process}

As Vygotsky (1978) contends, thought and speech are the essence of human consciousness and writing is speech in thought and image. If this is the case, it appears then that writing can be a means by which people can understand and refine their personal language development. It applies when they evaluate their own writing and seeing within it a reflection of their attitude toward learning and experience as seen in her recorded thoughts at different periods. In other words, Vygotsky's influence on the way teachers as social agent evaluate their existence within a wider society also applies in the context of reflection and reflective practices.

One of teachers' tasks after teaching is doing reflection on what they already taught in the classroom. Keeping teaching journals is one of many ways in the implementation of being reflective teachers as a means of evaluating their own instructional practices (Nurfaidah, 2016). Why should teachers keep reflecting on what they already delivered in the classroom? The class is over, so why should they bother? They need to reflect because teachers deal with human being in the classroom. To reflect on their classroom practices equals to evaluating their social and constructive interaction in the instructional context. In other words, their teaching and the way they reflect on it is part of their social process with their students in every classroom they enter. In line with Vygotsky's sociocultural approach, reflection lies in the heart of teaching as part of social process. Therefore, the act of teaching should be consistently reflected by the teacher.

Learning to teach, from a sociocultural perspective, based on the assumption that knowing, thinking, and understanding come from participating in the social practices of learning and teaching in the specific classroom and school situations. In line with Vygotskian perspective, Johnson (2009) informs that a sociocultural perspective on human learning informs several interrelated aspects of L2 teacher education. First, it explicates the cognitive processes at work in teacher learning. It provides us with a theory of mind that recognizes the inherent interconnectedness of the cognitive and the social. Second, a sociocultural perspective on L2 teacher education also recognizes that the education of teachers is not only a process of enculturation into the existing social practices associated with teaching and learning but also a dynamic process of reconstructing and transforming those practices to be responsive to both individual and local needs. 
Reflection is a process, both individual and collaborative, involving experience and uncertainty. It is comprised of identifying questions and key elements of a matter that has emerged as significant, then taking the teachers' thought into dialogue with himself and with others (Nurfaidah, Lengkanawati, \& Sukyadi, 2017; Nurfaidah, 2018). They evaluate insights gained from that process concerning additional perspectives, their own values, experiences, and beliefs, and the larger context within which the questions are raised. Through reflection, they reach newfound clarity, on which they base changes in their action or disposition. New questions, therefore, naturally arise, and the process spirals further (Farrell, 2015).

Teachers can, therefore, become more empowered decision makers, engaging in systematic reflections of their work by thinking, writing, and talking about their teaching; observing the acts of their own and others' teaching; and by estimating the impact of their teaching on their students' learning (Nurfaidah, et al., 2017). In these ways, teachers can begin to locate themselves within their profession and start to take more responsibility for shaping their practice (Farrell, 2004) and cultivating reflective dispositions into being openminded, responsible, and wholehearted reflective teachers (Dewey, 1933; Farrell, 2015; Nurfaidah, 2018).

\section{Critical Reflection in Sociocultural Dimension}

Critical reflection "involves teachers looking at all the different perspectives of a situation or problem and at all of the players involved: teachers, students, the school, and the community" (Farrell, 2004, p. 22). In this dimension of reflection, teachers as reflective practitioners are engaged in broader context of schooling, situating them as reflective practitioners who come to see themselves as agents of change. As regards, teachers are a reflective social agent who is capable of understanding not only what teaching is, but also working to create what teaching should be (Engestorm, 2001).

As part of reflective practice, critical reflective teaching is mostly realized by quality teachers - most of the time expert teachers (Nurfaidah, et al., 2017). Critical reflective practice requires both great effort and time from the teachers' side. It does not happen overnight; rather, it evolves in the teachers' continuum of professional development (Farrell, 2015). Only through a critical examination of experiences could teachers understand their own teaching practices and routines better. In another word, being a critically reflective teacher needs practice and time investment.

In cultivating reflective practice, Farrell's (2004) proposes a model of reflective teaching for teachers to implement. The model consists of five stages. First, teachers can embark on the reflective practice by going through keeping diaries, keeping teaching portfolios, discussing with peers, and observing other teachers' classrooms. This way engages the teachers to operate on sociocultural context. Teachers, as part of a larger schooling community, are required to interact with many people with various characteristics. There are times they play a role as a more knowledgeable others to their students. There are also times when the seek for assistance from colleagues or even expert when they need to consult problems they encounter in their instructional context. Second, a clear set of rules and regulations should be established for each and every activity so that they could serve all participants. As reflective practice takes part as teachers' teaching evaluation routines, it requires a commitment to faithfully practice it on a regular basis. 
Third, teachers need to plan for the four-time phase in the reflective practice. The four phases include: 1) individual time which is the time each teacher allots to reflect, the teachers can keep their journal writing. In group discussions and works, however, it is of paramount significance for every individual teacher to make it clear how much time he or she can devote to the reflective practice; 2) activity time which is the amount of time allocated for the different activities mentioned above; 3) development time which is the amount of time each individual has to spend in order to master higher levels of reflection which, again, varies in different individuals; and, 4) reflection time which refers to the time spent in group discussions. Reflection time consists of two-fold: "how often and for how long a period they want to meet as a group dedicated to reflective practice... [and] how much time within the group will be devoted to reflection itself?" (Farrell, 2004, p. 44),

Fourth, reflective teachers should not only have a kind of individual reflection but also try to keep contact with others and to keep themselves update about what is going on in the relevant literature on teaching, reflection, and related practices (Nguyen, 2017).It is in this essence that Vygotsky's sociocultural perspective plays a significant role in reflective practice. Last, since becoming involved in reflection can be considered a fundamental change in the teaching practice, the affective climate of the group discussion with others is very crucial to the efficiency and success of the group, hence providing a low-anxious context for group discussions (Farrel, 2004). This way also provides collaborative dialogue among colleagues in more supportive and constructive atmosphere.

\section{Conclusion}

Vygotsky's idea on sociocultural perspective has very much influence on the process of teaching and learning writing as a social process. The scaffolding in teaching writing, collaborative work activity in writing a lesson, as well as teacher reflection on teaching and learning activities in the classroom are all mainly grounded on his perspective. Teachers and learners, both as social agent in a wider schooling and educational context, play significant role in situating constructive learning context which could facilitate others to learn and reflect more from experiences. Within the activity theory, as one of Vygotsky's legacy, both teachers and students' drive in teaching and learning process could be further investigated. Therefore, it could facilitate the teacher educator and teacher education program to apply reflective approaches in the curriculum to create more reflective teacherswho are hopefully could develop into critical teachers - when they are faced with the real instructional context within wider society and more dynamic educational setting.

\section{References}

Ammar, A., \& Hassan, R. M. (2018). Taking it through: Collaborative dialogue and second language learning. Language Learning, 68(1), 46-82.

Cheung, Y. L. (2016). Teaching writing. In W. A. Renandya and H. P. Widodo (Eds.), English Language Teaching Today, pp. 179-194.

Dewey, J. (1933). How we think: A restatement of the relation of reflective thinking to the educative process. Boston, MA: DC Heath and Company. 
Engestörm, Y. (2001). Expansive learning at work: Toward an activity theoretical reconceptualization. Journal of Education and Work, 14(1), 133-156.

Farrell, T. (2004). Reflective Practice in Action: 80 Reflection Breaks for Busy Teachers. California: Corwin Press.

Farrell, T. S. C. (2012). Reflecting on reflective practice: (Re)Visiting Dewey and Schon. TESOL Journal 3(1), 7-16.

Farrell, T. S. C. (2013). Reflecting on ESL teacher expertise: A case study. System, 41, 1070-1082.

Farrell, T. S. (2015). “Teacher you are stupid!" - Cultivating a reflective disposition. The Electronic Journal for English as a Second Language, 18(3), 1-20.

Farrell, T. S. (2016). The practices of encouraging TESOL teachers to engage in reflective practice: An appraisal of recent research contributions. Language Teaching Research, 20(2), 223-247.

Johnson, K. E. (2009). Second Language Teacher Education: A Sociocultural Perspective. New York: Routledge.

Lantolf, J. P. (2011). Integrating sociocultural theory and cognitive linguistics in the second language classroom. In Eli Hinkel (Ed.), Handbook of Research in Second Language Teaching and Learning (Vol. II), pp. 303-318. New York: Routledge.

Lee, I. (2014). Teachers' reflection on implementation of innovative feedback approaches in EFL writing. English Language, 69(1), 23-40.

Lee, I. (2016). Teacher education on feedback in EFL writing: Issues, challenges, and future directions. TESOL Quarterly, 50(2), 518-527.

Leont'ev, A. N. (1974). The problem of activity in psychology. Soviet Psychology, 13(2), 4-33.

Mayordomo, R. M., \& Onrubia, J. (2015). Work coordination and collaborative knowledge construction in a small group collaborative virtual task. The Internet and Higher Education, 25, 96-104.

Nguyen, H. T. M. (2017). Models of mentoring in language teacher education. Switzerland: Springer.

Nurfaidah, S. (2016). EFL pre-service teachers' reflection: A case study in an Indonesian instructional context. (Unpublished doctoral dissertation), Indonesia University of Education.

Nurfaidah, S. (2018). Three attitudes of a reflective teacher. Research and Innovation in Language Learning, 1(1), 39-48.

Nurfaidah, S., Lengkanawati, N. S., \& Sukyadi, D. (2017). Levels of reflection in EFL pre-service teachers' teaching journal. Indonesian Journal of Applied Linguistics, $7(1), 80-92$.

Reitbauer, M., \& Fromm, H. (2016). Scaffolding 2.0-Redefining the role of the teacher in online language learning environments. In C. Gkonou, Dietmar Tatzl, 
and Sarah Mercer. (Eds.), New Directions in Language Learning Psychology, Second Language Learning and Teaching, pp. 233-247. New York: Springer.

Roth, W.-M., \& Lee, Y.-J. (2007). “Vygotsky's neglected legacy”: Cultural-historical activity theory. Review of Educational Research, 77(2), 186-232.

Samana, W. (2013). Teacher's and students' scaffolding in an EFL classroom. Academic Journal of Interdisciplinary Studies, 2(8), 338-343. doi: 10.5901/ajis.2013.v2n8p338

Shokouhi, M., Moghimi, S. A., \& Hosseinzadeh, S. (2015). Introducing reflective practice from a sociocultural perspective: Toward a strategically mediated reflective practice framework. Journal of Applied Linguistics and Language Research, 2(4), 74-83.

Storch, N. (2018). Written corrective feedback from sociocultural theoretical perspectives: A research agenda. Language Teaching, 51(2), 262-277.

Vygotsky, L. S. (1978). Mind in society: The development of higher psychological processes. In M. Cole, V. John-Steiner, S. Scribner, \& E. Souberman (Eds.). Cambridge, MA: Harvard University Press.

Vygotsky, L. S. (1986). Thought and language (Trans. and Ed. A. Kozulin). Cambridge, MA. MIT Press.

Wilson, K., \& Devereux, L. (2014). Scaffolding theory: High challenge, high support in Academic Language and Learning (ALL) contexts. Journal of Academic Language and Learning, 8(3), 91-100.

$\mathrm{Xu}, \mathrm{Z}$. (2016). Teaching academic writing in context. In W. A. Renandya and H. P. Widodo (Eds.), English Language Teaching Today, pp. 195-207. doi: 10.1007/978-3319-38834-2_14

Zacharias, N. T. (2014). Second language teacher contributions to student classroom participation: A narrative study of Indonesian learners. ELTWorldOnline, 6, 1-15.

Zeichner, K., Payne, K. A., \& Brayko, K. (2015). Democratizing teacher education. Journal of Teacher Education, 66(2), 122-135.

Zhang, J. (2013). Learner agency, motive, and self-regulated learning in an online ESL writing class. The IALLT Journal of Language Learning Technologies, 43(2), 57-81. 